\title{
A Methodological Framework to Support the Sustainable Innovation Development Process: A Collaborative Approach
}

\author{
Martha Orellano ${ }^{1, * \mathbb{D}}$, Christine Lambey-Checchin ${ }^{2}$, Khaled Medini $^{3}{ }^{\mathbb{D}}$ and Gilles Neubert ${ }^{4}$ \\ 1 Altran Technology Engineering Center, 31700 Blagnac, France \\ 2 CleRMa, Université Clermont Auvergne, 63000 Clermont-Ferrand, France; christine.lambey@uca.fr \\ 3 Mines Saint-Etienne, University Clermont Auvergne, CNRS UMR 6158 LIMOS, 42023 Saint-Étienne, France; \\ khaled.medini@emse.fr \\ 4 Emlyon Business School, CNRS UMR 5600 EVS, 42009 Saint-Étienne, France; gneubert@em-lyon.com \\ * Correspondence: martha.orellanoc@gmail.com
}

Citation: Orellano, M.;

Lambey-Checchin, C.; Medini, K.;

Neubert, G. A Methodological

Framework to Support the

Sustainable Innovation Development

Process: A Collaborative Approach.

Sustainability 2021, 13, 9054.

https://doi.org/10.3390/su13169054

Academic Editor: Jan Kratzer

Received: 1 July 2021

Accepted: 9 August 2021

Published: 12 August 2021

Publisher's Note: MDPI stays neutral with regard to jurisdictional claims in published maps and institutional affiliations.

Copyright: (c) 2021 by the authors. Licensee MDPI, Basel, Switzerland. This article is an open access article distributed under the terms and conditions of the Creative Commons Attribution (CC BY) license (https:// creativecommons.org/licenses/by/ $4.0 /)$.
Abstract: The notion of sustainable innovation (SI) emerged recently in the academic literature and evokes deep changes in organizations' products, processes, and practices to favour the creation of social and environmental value in addition to economic returns. The development of SI implies a collaborative process that requires the orchestration of several actors and streams of knowledge to be successful. Indeed, companies adopting the SI path need structured methodologies to guide the collaboration process with internal and external actors and support the decision process. Nevertheless, the literature has focused on the analysis of determinants and drivers of sustainable innovation development, while the process perspective has been discussed less. Through an in-depth case study in a large-sized company in France, this article proposes a methodological framework to guide the collaborative process in the early phases of sustainable innovation development. The framework relies on a combination of qualitative research and a multicriteria decision aiding method (AHP). The contributions of this work address two main aspects: (i) the conceptualization of sustainable innovation (SI) and (ii) the collaborative process between internal and external actors to develop SI. Firstly, our study leads to two additional dimensions to complete the concept of SI, traditionally based on the three pillars of sustainability (economic, environmental, and social), by adding the functional and relational dimensions. Secondly, concerning the collaborative process to develop SI, our framework proposes a structured methodology following five steps: definition of the project scope, setting actors' motivations, defining satisfaction criteria, proposing SI solutions, and performing a decision-aiding process to define the preference profiles of the key actors.

Keywords: sustainable innovation; customer-driven innovation; collaboration; decision-aiding; case study research

\section{Introduction}

Current sustainability-oriented standards and policies accord more responsibility to companies about their environmental and social impacts [1]. The notion of sustainable innovation (SI) has emerged as an alternative for companies to face such sustainability-related challenges [2]. SI is defined by [3] (p. 2) as "inventions in technology, process or market that simultaneously create economic and societal value. Societal value can be differentiated in protecting the environment, ensuring economic growth and advancing social well-being". This subject has been notably discussed in the last decade as evidenced in recent literature reviews [2,4,5]. Most of works have focused on the drivers and barriers to adopting sustainable innovations by companies [6-8]; and on the factors that determine sustainable innovation success [9-12]. Few researchers have explored SI from a process perspective, and their contributions are primarily conceptual (e.g., [13-16]). Methodological contributions using a collaborative approach to SI are still lacking, as mentioned by [17]. This author suggests that sustainable innovation is an iterative and collaborative process between several actors in the value 
network, which allows access to more knowledge and resources. However, it also implies a high degree of complexity to make decisions and find acceptable solutions. There is a need in the literature for a methodological approach to guide the collaborative process of sustainable innovation development.

This article reports on a methodological framework to support the sustainable innovation development process from a collaboration perspective, facilitating the decision-making process between multiple actors in the supply chain. Two main research questions guide this work:

- What are the dimensions characterizing the concept of sustainable innovation?

- How can actors' collaboration across the supply chain be supported during the process of sustainable innovation development?

The former question seeks to achieve a comprehensive conceptualization of sustainable innovation, considering the requirements from the customer point of view (i.e., the buyer company in a B2B context). The latter question refers to the need for a methodological approach structuring the collaboration process between several companies across the supply chain to develop SI. Such a methodological approach is necessary given the complexity of sustainable innovation, which includes economic, environmental, and social aspects simultaneously; and demands the collaboration between several actors inside and outside the company.

To answer these questions, firstly, we analyse previous literature addressing the notion of sustainable innovation, which provides an overview of the determinants, the drivers and barriers, and the development process of SI. Moreover, the analysis of previous literature allows to identify the limits and gaps to position our research contribution. Secondly, following a case study methodology within EDF (Electricté de France), we investigate the collaborative process between the company and its suppliers. A mixed methodology combining qualitative and quantitative approaches is implemented to carry out the case study. The qualitative approach is based on semi-structured interviews and workshops with the internal and external key actors involved in the project. The quantitative approach is based on AHP (Analytical Hierarchy Process), a multicriteria decision aid method, to support the collaborative process along the project. As a contribution, this paper provides a profound analysis of the collaborative process entailed in the early phases of sustainable innovation development, materialized throughout a methodological framework supported by the literature and the study analysis and results.

The structure of the paper is organized as follows: Section 2 presents a review of the literature. Section 3 introduces the methodological approach used to deploy the case study. Section 4 presents and discusses the case study results. Finally, the conclusions are presented in Section 5, providing the theoretical and managerial implications of this research.

\section{Theoretical Background}

\subsection{The Concept of Sustainable Innovation}

Fifty-four peer-reviewed articles published between 2005 and 2020 on sustainable innovation (SI) were analysed to identify the research trends and gaps and the theoretical basis to perform this research work. The literature reveals important efforts to delimit, clarify, and harmonize the concept of SI. On the one hand, several authors adopt the term 'green innovation' to emphasise on the environmental component of sustainable innovation [18-28]. On the other hand, some authors incorporate the three dimensions of sustainability, providing an extended definition of SI [3,29,30]. For instance, Rohrbeck et al. [3] (2013, p. 2) define SI as "inventions in technology, process or market that simultaneously create economic and societal value. Societal value can be differentiated in protecting the environment, ensuring economic growth and advancing social well-being". Moreover, from a process perspective, SI is characterised by a systemic nature, requiring diversified resources and knowledge and, therefore, multiple actors working in collaboration at internal and external levels of a company $[3,5,15,17]$. 
Despite the novelty of the SI concept, it is based on the historical concept of sustainable development: "development that meets the needs of the present without compromising the ability of future generations to meet their own needs" [31] (p. 54). Since then, the notion of sustainability has been extensively studied and applied in the academic literature and it is characterised by the economic, environmental, and social dimensions [32-34]. One of the most referred approaches to sustainability is known as Triple Bottom Line (TBL). This approach considers the three sustainability dimensions as equally important, allowing a compensation between them. Indeed, achieving gains in one dimension could mean a degradation of another one. Moreover, some researchers draw alternative approaches to sustainability [32-34]: the eco-efficiency and societal approaches. Eco-efficiency refers to a product-oriented vision of sustainability, focusing on the economic and the environmental dimensions [32,33]. In eco-efficiency, improving product functionalities allows achieving environmental gains (e.g., reducing the use of raw materials in eco-designed products, improving both economic and environmental dimensions). The societal approach supports the idea that the environmental and social dimensions are a priority face to the economic one, and it is supported by the global standards related to environmental management [35] (https:/ / www.iso.org/fr/standard/60857.html, accessed on 1 July 2021) and social responsibility [36] (https://www.iso.org/standard/42546.html, accessed on 1 July 2021).

Indeed, the notion of sustainable innovation reposes on the three dimensions of sustainability: economic, environmental, and social. Nevertheless, the application to industrial cases requires the definition of specific criteria to characterize each dimension, considering the industrial context and requirements [37]. Furthermore, beyond the conceptualization, sustainable innovation requires to be analysed throughout a process vision, which is still and understudied field of research [17].

\subsection{Thematic Analysis of the Sustainable Innovation Literature}

Three major themes have been distinguished in the reviewed literature: the drivers and barriers to SI, the determinants of SI, and the SI development process. Regarding Figure 1, the literature about SI has gained in importance over time. Early literature focuses on the drivers and barriers to adopting sustainable innovation into companies (e.g., $[7,8])$, which has remained a topic of interest along the subsequent years (e.g., [38-44]). Then, from 2014 to date, a considerable amount of research studies the determinants to develop successful sustainable innovations (e.g., [9-12,20,24,29,45-48], among others). Finally, the most recent and less explored topic refers to the process of sustainable innovation development (e.g., $[14,15,17,49,50])$. Furthermore, regarding Figure 2, the literature review reveals a prominent interest in SI at the enterprise level, which is naturally linked to the study of drivers and barriers and determinants of SI. In contrast, SI at the supply chain and network levels has been less studied, and is principally linked to the process perspective of SI.

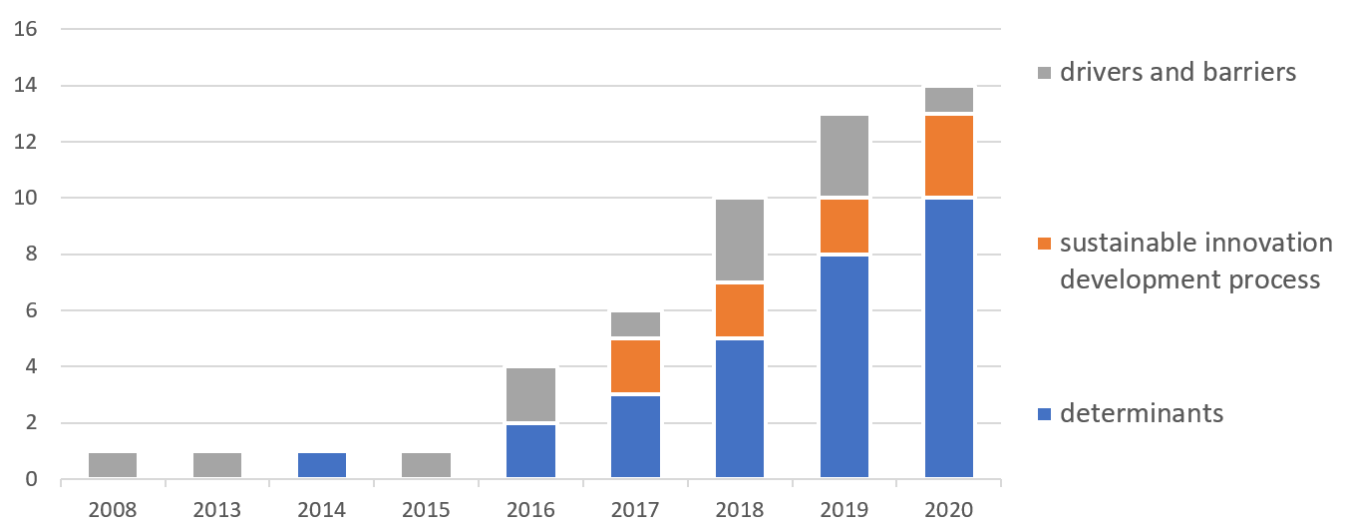

Figure 1. Distribution of publications according to the main topics of sustainable innovation over time. 
35

30

25

20

15

10

5

0
5

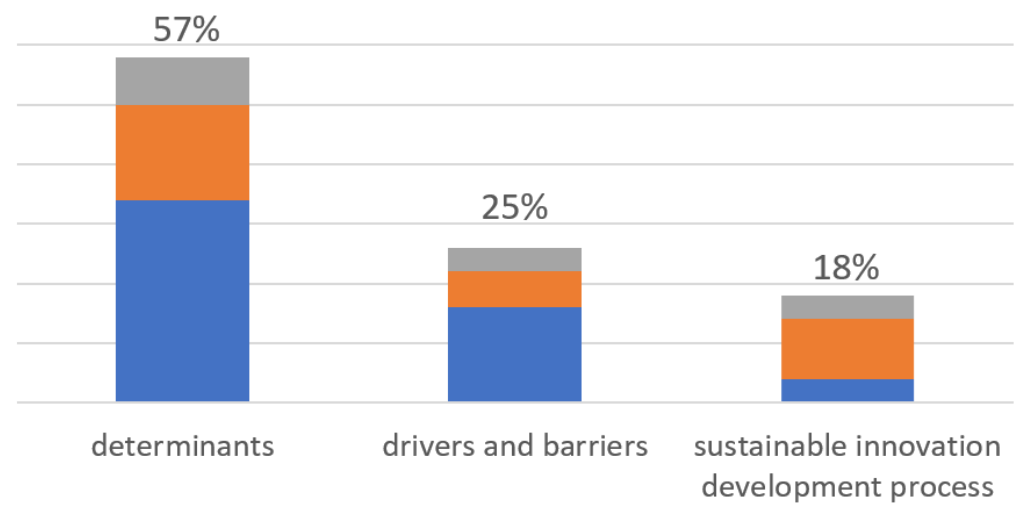

a supply chain

network

enterprise

Figure 2. Distribution of publications according to the main topics of sustainable innovation and collaboration level ( $* \%$ of total sample).

According to Figure 2, the biggest percentage of the consulted papers (57\%) explores the determinant factors to develop successful sustainable innovations, which is coherent with previous research observations [17]. The determinants of SI can be analysed according to the internal and external points of view with respect to a focal company. For instance, from the internal point of view, [13] explores the influence of the organisational learning capabilities and culture in the development of sustainable innovations. Specifically, the author reports on the capabilities and the resistance of company's internal actors to change their mindsets to pursuit sustainable goals. Similarly, [47] point out the importance of employees' creative thinking skills to promote successful SI development. In [20], it is argued that companies are more likely to succeed in sustainable innovation when the organisational culture, involving employees' values and beliefs, is aligned with the company's strategic goals related to sustainability. As well, internal actors who are proactive and search for new knowledge are more likely to contribute to the development of SI [20]. Moreover, from the external perspective, the authors of $[46,51]$ highlight the need for building trust-based and long-term relationships with the company's partners, which facilitates the access to new resources and knowledge, essential to the development of SI. The authors of [52] demonstrate throughout survey research that companies establishing collaborative relationships with innovative partners, coming from different and specialized domains of knowledge (e.g., environment experts) favour the development of successful radical SI. In the same vein, the study in [45] explores the influence of adopting an open innovation approach in the development of SI. The authors argue that the integration of public actors in the development of SI is essential to provide the means to transform traditional environment into innovative ones.

Secondly, $25 \%$ of the articles report on the drivers and barriers that motivate or prevent companies to develop sustainable innovations. Firstly, the authors of [53] analyse the external pressures that trigger companies to engage in SI. The authors identify and demonstrate the influence of three types of pressures coming from the government, the market, and the competitors. Thus, companies adopt a sustainable orientation to comply with regulations, ethical behaviour, and uncertain business environments. From a different perspective, Nielsen [1] argue that policies can be facilitators to SI development by promoting sustainable consumption and orienting end-users' preferences and choices. Secondly, concerning the internal perspective, an important factor preventing companies from adhering to SI projects are the perceived financial constraints [42]. For instance, in [7] it is explained that financial performance coming from SI is hard to perceive by the employees and decision-makers, which is a major barrier to engage in the SI path. Furthermore, adopting SI involves collaborative relationships with several actors in the supply chain, which implies relational risks, such as conflicting interests or opportunistic behaviour [42]. Finally, the authors of [39] propose a holistic framework from the literature analysis and categorise the drivers and barriers to SI into technical, market-oriented, socio-cultural, and regulatory. 
Finally, the remaining $18 \%$ of papers address the sustainable innovation development process, which is still an underexplored topic (cf. Figures 1 and 2). The next section outlines the existing literature on this theme.

\subsection{Sustainable Innovation Development Process}

Table 1 summarizes the articles treating the notion of sustainable innovation as a process, precising the research methodology and the type of contribution. To consider the collaborative approach, which is a core preoccupation of our research, the articles were classified according to the collaboration level considered in their research (i.e., enterprise, supply chain or network levels). Regarding the research methodological approaches, most of the papers apply a pure qualitative research, mostly based on single or multiple case studies. Two studies deploy a mixed research approach, combining qualitative and quantitative methodologies [17,54]. On the one side, [17] develops a single case study based on interviews, followed by a socio-technical graph method implementation. On the other side, [54] combine experts consulting and multicriteria analysis methods. The predominance of empirical and qualitative approaches highlights the exploratory stage of this research field.

Table 1. Articles about sustainable innovation development processes classified by research methodology and type of contribution.

\begin{tabular}{|c|c|c|c|c|c|}
\hline \multirow{2}{*}{ Reference } & \multirow{2}{*}{$\begin{array}{l}\text { Research } \\
\text { Design }\end{array}$} & \multicolumn{2}{|c|}{ Research Methodology } & \multirow{2}{*}{$\begin{array}{c}\text { Contribution } \\
\text { Type }\end{array}$} & \multirow{2}{*}{$\begin{array}{c}\text { Collaboration } \\
\text { Level }\end{array}$} \\
\hline & & Qualitative & Mixed & & \\
\hline [13] & case study & $x$ & & conceptualization & enterprise \\
\hline [49] & case study & $x$ & & case analysis & network \\
\hline [17] & case study & & $x$ & method proposal & network \\
\hline [14] & multi case study & $x$ & & conceptualization & enterprise \\
\hline [15] & multi case study & $x$ & & conceptualization & supply chain \\
\hline [16] & multi case study & $x$ & & conceptualization & network \\
\hline [50] & case study & $x$ & & conceptualization & network \\
\hline [54] & experts consulting & & $x$ & method proposal & supply chain \\
\hline
\end{tabular}

Most of the authors develop a conceptual contribution to SI process development literature. For instance, in [13] the organisational learning theory is used to investigate the capacity of organisations to build sustainable innovation capabilities thank to internal collaborative relationships. The authors of [16] elaborate a conceptual framework based on the Business Model framework, linking cultural organisation and internal capabilities with the establishment of collaborative mechanisms to trigger SI development. In the same vein, in [49] the Business Model framework is used to analyse the evolution of a longitudinal case study with respect to the collaborative approach with new external actors. Similarly, the authors of $[14,15]$ elucidate some collaborative mechanisms between the focal company and external actors, which should consider agreements on the resource investment of each actor, and define the relational governance conditions. Finally, addressing the importance of stakeholder implication, and based on multiple pieces of case study evidence, the authors of [50] propose several stakeholders roles manifested across the SI development process. For instance, stakeholders could initiate, stimulate, mediate, educate, or enable sustainable innovations, depending on their skills and beliefs, which is a critical aspect to successfully conducting a SI development process.

Furthermore, only two studies propose a methodological framework to support the SI development process. In both cases, the frameworks are built from a combined qualitative and quantitative research approach. Firstly, the study in [17] explores a single case in a SME context, with the aim of understanding the negotiation process entailed among several actors across the sustainable innovation development process. Although there is a underlying notion of collaboration approach in this research, the main findings and decisions are conducted by a single decision maker (i.e., the manager of the focal company), 
who defines the characteristics and scope of the sustainable innovation project, as well as the other actors' roles across the process. One of the limits of this work, as indicated by the author, is the unique consideration of the company's manager discourse and experience within the project of SI. Thus, further research is needed, considering a broader set of key actors' points of view. Secondly, Gupta and Barua [54] propose a framework for supplier selection based on their green innovation capabilities by applying decision aid approaches as the best-worst method coupled to the fuzzy TOPSIS method. The aim of this work is to support the process of supplier selection by a focal company, whereas the collaborative dimension of building sustainable innovation is not addressed.

Although the literature evokes the notion of collaboration between multiple actors as a key factor for the development of SI $[15,55,56]$, most of the consulted studies refer to the absorptive capacity of the focal company to acquire and exploit the external knowledge obtained from the partners $[6,51,57,58]$. The co-construction of knowledge during the collaborative process between the involved actors has not been sufficiently addressed. This ratifies the need for developing collaborative tools and methods to structure and support the SI development process.

\section{Materials and Methods}

This research employed an in-depth case study methodology carried out in EDF (Electricité de France, in French), a large-sized company in France, and world leader in energy production and distribution. The case study addressed a two-year innovation project, named ICOVET (Innovation Collaborative dans les Vêtements de Travail, in French), aiming at the transformation of the current supply model of safety clothing of EDF into a more sustainable one, considering the economic, environmental, and social impacts along the clothing life cycle. According to the authors of $[59,60]$, case study research is appropriate to study emerging or new research areas in which exploratory study is needed to get rich understanding of a given phenomenon. Furthermore, a single case study allows to deeply observe, analyse, and document the studied phenomenon. A mixed strategy combining qualitative and quantitative approaches was implemented to carry out this research.

\subsection{Qualitative Study}

The qualitative approach was supported on primary and secondary data. The former were collected throughout semi-structured interviews and the deployment of collaborative workshops between the key actors of the project, as recommended in case study research design [61]. Then, this data were complemented with the support of EDF's corporate documents.

The interviews were built based on literature review, starting with the identification of main topics, and then refined into a set of questions. The interviews were structured into two major sections, one oriented towards the study of the safety clothing market (the provider perspective), and the other one concerning EDF's expectations (the buyer perspective) about the desired safety clothing supply model. The three traditional dimensions of sustainability (economic, environmental, and social) were used during the interviews to explore actors' motivations and expectations regarding the project. Mostly open questions were asked to get the richest possible amount of information from the key actors. During the workshops, the dimensions of sustainability were refined into objectives and criteria.

Given the holistic nature of the problem, the interviews and workshops were addressed to several internal and external actors to EDF, classified according to the following categories:

- Internal actors: Thirteen interviews were performed with key actors from the departments of purchasing (project leader), prescription, sustainable development, human resources, research and development (R\&D), and the operational employees (users of the safety clothes).

- External actors: seven interviews were carried out with actors from the entire supply chain, involving clothes manufacturers, logistics providers, washing service providers, and end-of-life service providers. Moreover, non-economic actors (so- 
cial organizations) were integrated to the project with the aim at identifying further sustainable-oriented opportunities.

Finally, the interviews were recorded and transcribed ad verbatim.

\subsection{Quantitative Study}

As mentioned in previous research [3,15,51], a collaborative process implies dealing with an important amount of information from the different actors, and conflicting situations could emerge. To deal with that, this research proposes to use decision-aiding methods to formalize the decision process and to capitalize the collaborative knowledge. The Analytical Hierarchy Process (AHP) was proposed to effectuate a quantitative analysis of the gathered data from the previous stages of the qualitative study [62]. AHP allows to carry out the preference analysis of the key actors regarding the criteria and alternatives. The preference analysis consists of a pairwise comparison between the elements of each level of the hierarchy by using an ordinal scale from 1 to 9 [62]. According to [63], AHP has been used to support purchasing decisions in several contexts given its flexibility. For instance, it does not need quantitative data to effectuate the evaluation process, since it is based on the actors' judgments, following the ordinal scale. Furthermore, it allows to integrate several actors into the decision process [62]. Thus, in the early stages of sustainable innovation development, this method appears to be suitable, given the problem complexity, and the lack of information typical for innovation projects.

For the ICOVET project, an expert panel among the internal actors was selected to effectuate the AHP evaluation process. The expert panel was chosen considering two criteria: firstly, the strategic positioning on the company; and secondly, a high level of technical knowledge about the decisions considered in each stage of the safety clothing life cycle. Sixteen actors from the different functions (purchasing, R\&D, human resources, prescription, and sustainable development) were selected to perform the evaluation process using the AHP method. The evaluation was performed by the means of an online questionnaire using the software Sphinx. The questionnaires were built and tested within an iterative improvement process in collaboration with the purchasing department to ensure conceptual clarity and usability. Moreover, the questionnaires were answered with the guidance of the research team and supported by a prepared documentation about the sustainability-oriented criteria in the context of safety clothing. The data analysis was performed by the research team, and the results were shared with the key actors for validation and discussion at the end of the project. The purchasing direction was a key actor to engage the key actors in this process.

\section{Results and Discussion}

\subsection{Case Study Context}

The sustainable innovation project addressed in this study, called ICOVET (Innovation Collaborative dans les Vêtements de Travail, in French), emerged from the evolution of the Corporate Social Responsibility (CSR) strategy of EDF Group. The ICOVET project aims at the transformation of the safety clothing system of the company considering the economic, environmental, and social impacts along its life cycle. In the traditional system, the safety clothes belong to EDF's employees, who are fully responsible for their usage, maintenance, and recycling. About 44,000 employees of EDF wear safety clothes and should be reprovisioned each year, representing a considerable amount of indirect purchasing. Furthermore, according to [64], the production of safety clothing, primarily in cotton, is characterised by the consumption of huge amounts of water, energy, and a variety of chemical products polluting air and water. Moreover, as a global supply chain, it implies long-circuits transportation, translated into a large carbon footprint.

Considering the above panorama, the purchasing direction of EDF, in collaboration with the the department of sustainable development, launched ICOVET, a two-year project (2017-2019) of sustainable innovation related to safety clothing. The aim of the project was to transform the traditional system of safety clothing of the company, moving from a 
product purchasing logic towards the acquisition of a global solution, which fits the best the sustainability requirements of the company. The purchasing direction, being at the initiative, was the project leader, and had a role of ensuring project communication, actors' coordination, and result verification.

\subsection{Qualitative Study}

The aim of the qualitative study concerns the delimitation of the project (identification of the key internal and external actors); the identification of actors' motivations and expectations to engage in the project; and the translation of those expectations into criteria of satisfaction (customer perspective), and solutions (provider perspective). Figure 3 represents the key actors considered within the scope of the project.

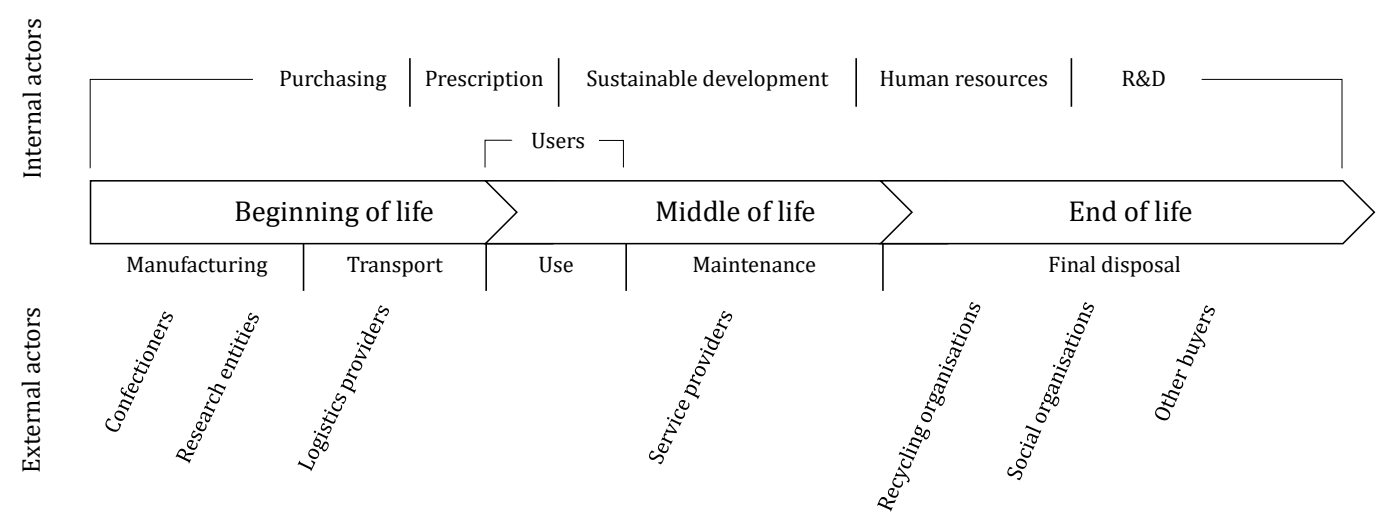

Figure 3. Key actors of the ICOVET project along the life cycle of the safety clothing.

\subsubsection{Setting Actors' Motivations and Expectations}

The aim of this phase was to capitalize and formalize the objectives of the key internal and external actors with respect to the sustainability-oriented innovation for the safety clothing. To perform this phase, internal and external workshops were carried out in 2017. Thirteen internal actors belonging to the departments of purchasing (project leader), prescription, sustainable development, human resources, research \& development $(R \& D)$ were interviewed.

Concerning the suppliers, key contractual and potential suppliers along the offer life cycle were considered, with the aim of understanding the suppliers' capabilities to meet EDF expectations in terms of sustainable innovations. Table 2 summarizes the interviews performed during this phase.

Internally, EDF launched a communication campaign with the employees about the importance of sustainable practices along with the company, and the specific challenges of the safety clothing. To create internal synergy and to reduce the risk of resistance to the project, the purchasing function involved key actors from the function of sustainable development, prescription, human resources, $R \& D$, and the operational employees (users) in the project governance. 
Table 2. Interviews conducted during 2017 with internal and external actors.

\begin{tabular}{cclc}
\hline Internal Actors & \multicolumn{1}{c}{ Date } & Function & Duration \\
\hline 1 & 31 October 2017 & Purchasing department (group interview) & $01: 34: 23$ \\
2 & 31 October 2017 & Indirect purchasing & $00: 47: 39$ \\
3 & 31 October 2017 & Purchasing-distribution & $00: 48: 19$ \\
4 & 31 October 2017 & Purchasing-nuclear safety clothing & $00: 49: 01$ \\
5 & 14 November 2017 & Sustainable development direction & $00: 56: 25$ \\
6 & 14 November 2017 & R\&D engineering & $00: 40: 10$ \\
7 & 14 November 2017 & Sustainable development direction & $00: 47: 44$ \\
8 & 14 November 2017 & Prescription-industrial safety & $00: 51: 39$ \\
9 & 14 November 2017 & Human Resources & $01: 38: 48$ \\
10 & 14 November 2017 & Prescription & $00: 45: 52$ \\
11 & 14 November 2017 & Prescription-waste management & $01: 41: 46$ \\
12 & 27 November 2017 & Social dialogue direction-CSR & $00: 39: 53$ \\
13 & 4 December 2017 & Human resources-normative expert & $00: 30: 28$ \\
\hline External Actors & & & $00: 44: 55$ \\
14 & 5 December 2017 & Clothes manufacturer & $00: 40: 17$ \\
15 & 5 December 2017 & Logistics provider & $00: 45: 18$ \\
16 & 5 December 2017 & Washing service provider & $00: 46: 55$ \\
17 & 5 December 2017 & Logistics, washing and location service provider & $00: 18: 30$ \\
19 & 5 December 2017 & Waste management-energy recovery & $01: 42: 21$ \\
20 & 19 December 2017 & Recycling organisation & $00: 46: 00$ \\
\hline
\end{tabular}

Concerning the suppliers, several strategies for collaborative relationships were discussed between EDF and its actual and potential suppliers. Firstly, EDF's suppliers' motivations to collaborate in a sustainable innovation project were primarily based on cost and risk sharing, but also in the corporate image improvement obtained from sustainabilityoriented initiatives. However, several limitations of the supplier to fulfil new requirements related to sustainability-oriented innovation were identified: the investment costs of innovation, the expected amount of purchasing of the future sustainable offer of safety clothing, the legal and technical limitations, the supply chain transformation, among others. Such constraints allowed consolidating the real possibilities of the project and the time-horizon needed to be achieved. Secondly, the buyer-supplier discussions during this step allowed the potential entry of new suppliers to the EDF's panel.

\subsubsection{Criteria Definition}

From the workshop and interviews carried out in 2017 with the key internal actors, the strategic objectives were identified, corresponding to the sustainability dimensions and the aspects to be integrated in the future safety clothing supply model. As a first result, beyond the three sustainability dimensions of economic, social, and environmental, two additional dimensions were identified according to the collaborative analysis with the internal actors, corresponding to functional and relational dimensions. The five dimensions were defined as follows:

(E) Economics: this dimension focuses on reducing the purchasing costs, and developing new market niches in France based on circular economy strategies throughout the transformation of the waste clothing into new resources.

(N) Environmental: implementing an environmental management plan over the entire system of safety clothing, focusing on supplier management and waste treatment policies. (S) Social: guaranteeing the respect of the human rights in the manufacturing countries (of safety clothing), decent conditions of employment, and development of the French economy. (R) Relational: establishing long-term relationships with providers, sharing responsibilities, and promoting collaboration for innovation development.

(F) Functional: improving the lifespan of the safety clothes, establishing a system based on the clothes availability to use, rather than the traditional product reprovisioning.

Then, those objectives were refined into specific sustainability-oriented criteria. This constituted an iterative, exhaustive, and extensive process carried out with the key internal actors, during a collaborative workshop performed by work teams. Each team was com- 
posed by actors from different functions, and the aim was to identify a set of criteria for each sustainability dimension, establishing the link with EDF's Corporate Social Responsibility (CSR) strategy. The criteria were analysed and synthesized by the research group, and then validated with the participants. For this step, the head of the purchasing direction was a key actor to engage the other functions in the use of the different tools and methodologies. This step was an iterative process, resulting on a synthesized list of criteria used to evaluate sustainability-oriented innovations related to the safety clothing (Table 3).

Table 3. Evaluation criteria for the sustainable safety clothing.

\begin{tabular}{|c|c|c|c|}
\hline SI Dimension & Criterion & Sense & Description \\
\hline \multirow{5}{*}{ Environmental } & $\begin{array}{l}\text { Environmental quality of } \\
\text { the fibre }\end{array}$ & + & $\begin{array}{l}\text { It includes a multiple-criteria evaluation taking into account: the country } \\
\text { of production, the feasibility of production, the possibility to recycle the } \\
\text { fibre, the emissions to the air due to the transport of raw materials, water } \\
\text { consumption, the use of chemical products, energy consumption, and the } \\
\text { price per kg of fibre. }\end{array}$ \\
\hline & $\begin{array}{l}\text { Environmental } \\
\text { performance of providers }\end{array}$ & + & $\begin{array}{l}\text { Provider performance category according to the auditory score (bad, } \\
\text { acceptable, good, very good). }\end{array}$ \\
\hline & Carbon footprint & - & $\begin{array}{l}\text { Corresponds to the quantity of } \mathrm{CO}_{2} \text { equivalent emitted to the air in the } \\
\text { activities of transportation (from producer to the customer) and washing. }\end{array}$ \\
\hline & Chemical use & - & $\begin{array}{l}\text { Quantity of chemical used during the washing process, generating water } \\
\text { pollution, and possible health damages. }\end{array}$ \\
\hline & Recycling capability & + & $\begin{array}{l}\text { Capability of the system to enable recycling expressed as the percentage of } \\
\text { recycled material at the end of life. }\end{array}$ \\
\hline \multirow[t]{2}{*}{ Economic } & Life cycle costs & - & $\begin{array}{l}\text { Expected costs of the entire life cycle, including the cost of waste } \\
\text { transformation. }\end{array}$ \\
\hline & Purchasing cost & - & Cost to acquire a product or a service, including indirect costs. \\
\hline \multirow{4}{*}{ Social } & $\begin{array}{l}\text { Social performance } \\
\text { of providers }\end{array}$ & + & $\begin{array}{l}\text { Provider category assignment according to the auditory (bad, acceptable, } \\
\text { good, very good). }\end{array}$ \\
\hline & New job generation & + & $\begin{array}{l}\text { Number of new jobs in relation to the new system implementation (entire } \\
\text { supply chain/life cycle of the offer). }\end{array}$ \\
\hline & $\begin{array}{l}\text { Employees resistance } \\
\text { to change }\end{array}$ & + & Percentage of employees rejecting the new safety clothing system. \\
\hline & Responsible purchasing & + & $\begin{array}{l}\text { Percentage services purchased to socially-engaged organisations in France } \\
\text { (Secteur Adapté et Protégé (French)). }\end{array}$ \\
\hline \multirow{2}{*}{ Relational } & $\begin{array}{l}\text { Contribution to the } \\
\text { brand image }\end{array}$ & + & $\begin{array}{l}\text { Level of the positive impact on the image of EDF in relation to the } \\
\text { adoption of sustainable alternatives. }\end{array}$ \\
\hline & $\begin{array}{l}\text { Level of innovation } \\
\text { sharing }\end{array}$ & + & $\begin{array}{l}\text { New knowledge (in terms of processes and competencies) acquired } \\
\text { through the collaboration: high, medium, low, none. }\end{array}$ \\
\hline \multirow{6}{*}{ Functional } & $\begin{array}{l}\text { Guarantee of the } \\
\text { fibre quality }\end{array}$ & + & $\begin{array}{l}\text { Level of mechanic resistance of the fibre monitored through different type } \\
\text { of tests (simulation, real-life). }\end{array}$ \\
\hline & $\begin{array}{l}\text { Availability of } \\
\text { safety clothing }\end{array}$ & + & Level of service provided during the process of distribution. \\
\hline & Guarantee of lifespan & + & $\begin{array}{l}\text { Number of washing according to historical data from service providers } \\
\text { at MOL. }\end{array}$ \\
\hline & Comfort & + & $\begin{array}{l}\text { Related to the ergonomics of safety clothes verified during the execution of } \\
\text { the corresponding activities: breathability, adapted to weather conditions, } \\
\text { adapted to activity, meeting the employees' needs. }\end{array}$ \\
\hline & $\begin{array}{l}\text { Efficiency level of } \\
\text { the tracking }\end{array}$ & + & $\begin{array}{l}\text { Level of service provided during the washing process. Considering the } \\
\text { historical data with ancient providers. }\end{array}$ \\
\hline & Waste upgrading level & + & $\begin{array}{l}\text { Capability to dismantle the safety clothing and use it as a resource for a } \\
\text { new production cycle, measured as the percentage of recovered material. }\end{array}$ \\
\hline
\end{tabular}




\subsubsection{Alternative Definition with Suppliers}

By means of phone interviews and a second workshop carried out on December 2018, internal and external actors were asked to generate ideas of solutions to match EDF's criteria for sustainable innovation. Individual interviews by phone were carried out with eight users of safety clothing, with the aim of understanding their needs and expectations about the clothing. Then, a collaborative workshop between EDF key actors and 10 engaged providers, principally clothes manufacturers, was conducted to detail the offers. Table 4 details the interviews carried out in this phase of the project.

Table 4. Interviews conducted during 2018 with safety clothing users and external actors.

\begin{tabular}{cclc}
\hline Users & \multicolumn{1}{c}{ Date } & Function & Time (hh/mm/ss) \\
\hline 1 & 17 September 2018 & Project management-environment & $00: 34: 45$ \\
2 & 17 September 2018 & Mechanic team managerment & $00: 22: 16$ \\
3 & 17 September 2018 & National preventor & $00: 26: 57$ \\
4 & 17 September 2018 & Operator-renewable energy & $00: 20: 41$ \\
5 & 17 September 2018 & Operator-renewable energy & $00: 31: 41$ \\
6 & 17 September 2018 & Operator-Enedis & $00: 24: 21$ \\
7 & 01 October 2018 & Operator-Electricité de Strasbourg & $00: 22: 30$ \\
8 & 08 October 2018 & Operator-EDF group & $00: 30: 00$ \\
\hline External Actors & & & \\
\hline 9 & 11 December 2018 & Clothes manufacturer A & $00: 30: 00$ \\
10 & 11 December 2018 & Clothes manufacturer B & $00: 30: 00$ \\
11 & 11 December 2018 & Clothes manufacturer C & $00: 30: 00$ \\
12 & 11 December 2018 & Clothes manufacturer D & $00: 30: 00$ \\
13 & 11 December 2018 & Clothes manufacturer E & $00: 30: 00$ \\
14 & 11 December 2018 & Clothes manufacturer F & $00: 30: 00$ \\
15 & 11 December 2018 & Clothes manufacturer G & $00: 30: 00$ \\
16 & 11 December 2018 & Clothes manufacturer H & $00: 30: 00$ \\
17 & 11 December 2018 & Logistics service provider & $00: 30: 00$ \\
18 & 11 December 2018 & Recycling organisation & $00: 30: 00$ \\
\hline
\end{tabular}

At the end of this phase, it was possible to draw out the decisions to make for each stage of the life cycle.

(BOL) Beginning of life: the main decision concerns the type of fibre used to manufacture the safety clothes. A critical aspect for the providers in terms of sustainability is the country of production, hence, a mix between Asian, North African, and European production was considered. After a brainstorming session integrating providers capabilities and EDF criteria for the future model, three fibre options were retained: poly-cotton, organic cotton, and tencel (eucalyptus-based fibre).

(MOL) Middle of life: decisions in this stage focus on the washing system (localised or centralised) and on the type of technology used for ensuring clothes traceability (RFID tag or bar code).

(EOL) End of life: decisions concern the system for waste upgrading and the opportunities to develop new markets in France by using the wasted textile. Three options resulted from the providers interviews: new product, second-life safety clothing, energy recovery (i.e., from incineration).

\subsection{Quantitative Study}

Based on the Analytical Hierarchy Process (AHP) [62], this section presents the results from the actors' priorities with respect to sustainable innovation dimensions and criteria, as well as the preferred alternatives for each stage of the life cycle. This phase of the methodology was carried out in 2019, after the criteria and alternatives were clearly defined and communicated to all the actors of the project. 
From the individual evaluations, applying the AHP method, the following insights were obtained. At the beginning of life, nine actors were in the evaluation panel. Most of the actors agree that environmental and social dimensions are a priority for the purchasing strategy regarding safety clothes (cf. Tables 5 and 6). In general, economic and relational dimensions are the less important for the actors when regarding decision related to the type of fibre. Moreover, the alternative "Tencel" appears to be the most suitable regarding all the criteria and all the actors, while organic cotton is the less preferred.

Table 5. Relative importance of the sustainable innovation dimensions and criteria at the beginning of life. $\left(\mathrm{A}_{n}=\right.$ Actor; AIP = Aggregation of Individual Priorities).

\begin{tabular}{|c|c|c|c|c|c|c|c|c|c|c|}
\hline Criterion & A1 & A2 & A3 & A4 & A5 & A6 & A7 & A8 & A9 & AIP \\
\hline Environmental & $45 \%$ & $15 \%$ & $42 \%$ & $31 \%$ & $40 \%$ & $27 \%$ & $44 \%$ & $34 \%$ & $32 \%$ & $35 \%$ \\
\hline Fibre quality & $75 \%$ & $50 \%$ & $50 \%$ & $75 \%$ & $83 \%$ & $83 \%$ & $25 \%$ & $50 \%$ & $83 \%$ & $64 \%$ \\
\hline Providers env. performance & $25 \%$ & $50 \%$ & $50 \%$ & $25 \%$ & $17 \%$ & $17 \%$ & $75 \%$ & $50 \%$ & $17 \%$ & $36 \%$ \\
\hline Social & $28 \%$ & $21 \%$ & $15 \%$ & $19 \%$ & $21 \%$ & $49 \%$ & $25 \%$ & $22 \%$ & $32 \%$ & $26 \%$ \\
\hline Providers soc. performance & $88 \%$ & $75 \%$ & $50 \%$ & $17 \%$ & $83 \%$ & $83 \%$ & $17 \%$ & $88 \%$ & $17 \%$ & $57 \%$ \\
\hline User resistance & $12 \%$ & $25 \%$ & $50 \%$ & $83 \%$ & $17 \%$ & $17 \%$ & $83 \%$ & $12 \%$ & $83 \%$ & $43 \%$ \\
\hline Functional & $4 \%$ & $34 \%$ & $27 \%$ & $33 \%$ & $11 \%$ & $10 \%$ & $4 \%$ & $15 \%$ & $7 \%$ & $16 \%$ \\
\hline Fibre quality & $83 \%$ & $50 \%$ & $83 \%$ & $88 \%$ & $75 \%$ & $25 \%$ & $88 \%$ & $75 \%$ & $13 \%$ & $64 \%$ \\
\hline Availability & $17 \%$ & $50 \%$ & $17 \%$ & $12 \%$ & $25 \%$ & $75 \%$ & $12 \%$ & $25 \%$ & $87 \%$ & $36 \%$ \\
\hline Relational & $14 \%$ & $25 \%$ & $8 \%$ & $5 \%$ & $18 \%$ & $6 \%$ & $19 \%$ & $22 \%$ & $12 \%$ & $14 \%$ \\
\hline Brand image & $50 \%$ & $83 \%$ & $50 \%$ & $88 \%$ & $50 \%$ & $50 \%$ & $88 \%$ & $83 \%$ & $50 \%$ & $66 \%$ \\
\hline Innovation & $50 \%$ & $17 \%$ & $50 \%$ & $12 \%$ & $50 \%$ & $50 \%$ & $12 \%$ & $17 \%$ & $50 \%$ & $34 \%$ \\
\hline Economic & $10 \%$ & $5 \%$ & $8 \%$ & $12 \%$ & $9 \%$ & $9 \%$ & $8 \%$ & $7 \%$ & $17 \%$ & $9 \%$ \\
\hline Life cycle costs & $83 \%$ & $88 \%$ & $50 \%$ & $88 \%$ & $50 \%$ & $88 \%$ & $88 \%$ & $88 \%$ & $75 \%$ & $77 \%$ \\
\hline Purchasing cost & $17 \%$ & $12 \%$ & $50 \%$ & $12 \%$ & $50 \%$ & $12 \%$ & $12 \%$ & $12 \%$ & $25 \%$ & $23 \%$ \\
\hline
\end{tabular}

Table 6. Relative importance of the alternatives at the beginning of life.

\begin{tabular}{lcccccccccc}
\hline Alternative & A1 & A2 & A3 & A4 & A5 & A6 & A7 & A8 & A9 & AIP \\
\hline Tencel & $56 \%$ & $48 \%$ & $35 \%$ & $35 \%$ & $45 \%$ & $43 \%$ & $55 \%$ & $36 \%$ & $43 \%$ & $44 \%$ \\
Poly-cotton & $21 \%$ & $36 \%$ & $38 \%$ & $37 \%$ & $27 \%$ & $29 \%$ & $14 \%$ & $20 \%$ & $25 \%$ & $28 \%$ \\
Organic cotton & $23 \%$ & $16 \%$ & $27 \%$ & $28 \%$ & $28 \%$ & $28 \%$ & $31 \%$ & $44 \%$ & $32 \%$ & $28 \%$ \\
\hline
\end{tabular}

At the middle of life, the evaluation panel was made up of twelve experts. The results vary considerab;y from one actor to another (cf. Tables 7 and 8). A first group of actors considers environmental and social dimensions as the priority; a second group focuses on economic, functional, and environmental dimensions; and the third group is rather neutral, considering that all the dimensions have similar importance. Here, actors' opinions are very conflicting regarding the prioritization of value dimensions. Nevertheless, all the actors consider that the alternative "localised washing system" is the most suitable solution at the middle of life.

Finally, at the end of life, the evaluation was performed by eight experts (cf. Tables 9 and 10). The environmental, social, and economic dimensions are the most important to take into account to evaluate the offer. The economic dimension gained in importance with respect to the beginning and middle of life. It reflects the actors' expectations to create new markets from circular economy strategies, but also the interest in paying as little as possible for services at the end of life, to avoid an important increase on the current purchasing costs. Concerning the alternatives, the actors reject the energy recovery solution, and the majority prefer the waste transformation into on a new product. 
Table 7. Relative importance of the sustainable innovation dimensions and criteria at the middle of life. $\left(\mathrm{A}_{n}=\right.$ Actor; AIP = Aggregation of Individual Priorities).

\begin{tabular}{|c|c|c|c|c|c|c|c|c|c|c|c|c|c|}
\hline Criterion & A1 & A2 & A3 & A4 & A5 & A6 & A7 & A8 & A9 & A10 & A11 & A12 & AIP \\
\hline Environmental & $49 \%$ & $21 \%$ & $41 \%$ & $16 \%$ & $25 \%$ & $49 \%$ & $53 \%$ & $19 \%$ & $38 \%$ & $30 \%$ & $22 \%$ & $6 \%$ & $31 \%$ \\
\hline Carbon footprint & $50 \%$ & $50 \%$ & $50 \%$ & $83 \%$ & $17 \%$ & $83 \%$ & $88 \%$ & $13 \%$ & $90 \%$ & $50 \%$ & $83 \%$ & $50 \%$ & $59 \%$ \\
\hline Chemicals use & $50 \%$ & $50 \%$ & $50 \%$ & $17 \%$ & $83 \%$ & $17 \%$ & $12 \%$ & $87 \%$ & $10 \%$ & $50 \%$ & $17 \%$ & $50 \%$ & $41 \%$ \\
\hline Social & $24 \%$ & $31 \%$ & $32 \%$ & $12 \%$ & $24 \%$ & $28 \%$ & $18 \%$ & $25 \%$ & $10 \%$ & $27 \%$ & $49 \%$ & $55 \%$ & $28 \%$ \\
\hline Local jobs & $45 \%$ & $24 \%$ & $14 \%$ & $43 \%$ & $49 \%$ & $45 \%$ & $28 \%$ & $24 \%$ & $11 \%$ & $45 \%$ & $35 \%$ & $33 \%$ & $33 \%$ \\
\hline User resistance & $9 \%$ & $28 \%$ & $49 \%$ & $14 \%$ & $37 \%$ & $9 \%$ & $6 \%$ & $21 \%$ & $11 \%$ & $9 \%$ & $9 \%$ & $33 \%$ & $20 \%$ \\
\hline Responsible purchasing & $45 \%$ & $48 \%$ & $37 \%$ & $43 \%$ & $14 \%$ & $45 \%$ & $66 \%$ & $55 \%$ & $78 \%$ & $45 \%$ & $6 \%$ & $33 \%$ & $43 \%$ \\
\hline Functional & $4 \%$ & $23 \%$ & $9 \%$ & $42 \%$ & $17 \%$ & $5 \%$ & $4 \%$ & $19 \%$ & $28 \%$ & $27 \%$ & $9 \%$ & $6 \%$ & $16 \%$ \\
\hline Lifespan & $26 \%$ & $14 \%$ & $45 \%$ & $13 \%$ & $33 \%$ & $66 \%$ & $21 \%$ & $49 \%$ & $20 \%$ & $44 \%$ & $7 \%$ & $33 \%$ & $31 \%$ \\
\hline Comfort & $63 \%$ & $33 \%$ & $45 \%$ & $75 \%$ & $33 \%$ & $19 \%$ & $55 \%$ & $37 \%$ & $60 \%$ & $39 \%$ & $64 \%$ & $33 \%$ & $46 \%$ \\
\hline Traceability & $11 \%$ & $53 \%$ & $10 \%$ & $12 \%$ & $34 \%$ & $15 \%$ & $24 \%$ & $14 \%$ & $20 \%$ & $17 \%$ & $29 \%$ & $34 \%$ & $23 \%$ \\
\hline Economic & $12 \%$ & $5 \%$ & $10 \%$ & $26 \%$ & $11 \%$ & $12 \%$ & $10 \%$ & $16 \%$ & $13 \%$ & $8 \%$ & $14 \%$ & $25 \%$ & $14 \%$ \\
\hline Relational & $12 \%$ & $21 \%$ & $8 \%$ & $4 \%$ & $23 \%$ & $5 \%$ & $14 \%$ & $19 \%$ & $12 \%$ & $9 \%$ & $5 \%$ & $6 \%$ & $12 \%$ \\
\hline Brand image & $25 \%$ & $50 \%$ & $88 \%$ & $83 \%$ & $50 \%$ & $13 \%$ & $88 \%$ & $17 \%$ & $13 \%$ & $75 \%$ & $75 \%$ & $50 \%$ & $52 \%$ \\
\hline Innovation & $75 \%$ & $50 \%$ & $13 \%$ & $17 \%$ & $50 \%$ & $88 \%$ & $13 \%$ & $83 \%$ & $88 \%$ & $25 \%$ & $25 \%$ & $50 \%$ & $48 \%$ \\
\hline
\end{tabular}

Table 8. Relative importance of the alternatives at the middle of life.

\begin{tabular}{|c|c|c|c|c|c|c|c|c|c|c|c|c|c|}
\hline Alternative & A1 & A2 & A3 & A4 & A5 & A6 & A7 & A8 & A9 & A10 & A11 & A12 & AIP \\
\hline Local washing & $67 \%$ & $79 \%$ & $58 \%$ & $80 \%$ & $59 \%$ & $54 \%$ & $74 \%$ & $73 \%$ & $88 \%$ & $54 \%$ & $73 \%$ & $47 \%$ & $68 \%$ \\
\hline Centralised washing & $33 \%$ & $21 \%$ & $42 \%$ & $20 \%$ & $41 \%$ & $46 \%$ & $26 \%$ & $27 \%$ & $12 \%$ & $37 \%$ & $23 \%$ & $53 \%$ & $32 \%$ \\
\hline
\end{tabular}

Table 9. Relative importance of the sustainable innovation dimensions and criteria at the end of life. $\left(\mathrm{A}_{n}=\right.$ Actor; $\mathrm{AIP}=$ Aggregation of Individual Priorities $)$.

\begin{tabular}{|c|c|c|c|c|c|c|c|c|c|}
\hline Criterion & A1 & A2 & A3 & A4 & A5 & A6 & A7 & A8 & AIP \\
\hline Environmental & $46 \%$ & $53 \%$ & $21 \%$ & $41 \%$ & $20 \%$ & $49 \%$ & $17 \%$ & $16 \%$ & $33 \%$ \\
\hline Carbon footprint & $17 \%$ & $17 \%$ & $17 \%$ & $17 \%$ & $17 \%$ & $17 \%$ & $17 \%$ & $17 \%$ & $17 \%$ \\
\hline Recycling & $83 \%$ & $83 \%$ & $83 \%$ & $83 \%$ & $83 \%$ & $83 \%$ & $83 \%$ & $83 \%$ & $83 \%$ \\
\hline Social & $20 \%$ & $13 \%$ & $12 \%$ & $38 \%$ & $20 \%$ & $7 \%$ & $54 \%$ & $40 \%$ & $26 \%$ \\
\hline Local job & $63 \%$ & $66 \%$ & $41 \%$ & $72 \%$ & $7 \%$ & $45 \%$ & $18 \%$ & $41 \%$ & $44 \%$ \\
\hline User resistance & $11 \%$ & $16 \%$ & $11 \%$ & $8 \%$ & $7 \%$ & $9 \%$ & $70 \%$ & $11 \%$ & $18 \%$ \\
\hline Responsible purchasing & $26 \%$ & $19 \%$ & $48 \%$ & $19 \%$ & $7 \%$ & $45 \%$ & $11 \%$ & $48 \%$ & $28 \%$ \\
\hline Economic & $10 \%$ & $5 \%$ & $21 \%$ & $8 \%$ & $20 \%$ & $20 \%$ & $19 \%$ & $22 \%$ & $16 \%$ \\
\hline Functional & $4 \%$ & $15 \%$ & $41 \%$ & $6 \%$ & $20 \%$ & $18 \%$ & $5 \%$ & $12 \%$ & $15 \%$ \\
\hline Relational & $20 \%$ & $13 \%$ & $5 \%$ & $6 \%$ & $20 \%$ & $7 \%$ & $5 \%$ & $10 \%$ & $11 \%$ \\
\hline Brand image & $25 \%$ & $50 \%$ & $83 \%$ & $17 \%$ & $50 \%$ & $50 \%$ & $83 \%$ & $50 \%$ & $51 \%$ \\
\hline Innovation & $75 \%$ & $50 \%$ & $17 \%$ & $83 \%$ & $50 \%$ & $50 \%$ & $17 \%$ & $50 \%$ & $49 \%$ \\
\hline
\end{tabular}

Table 10. Relative importance of the alternatives at the end of life.

\begin{tabular}{lccccccccc}
\hline Alternative & A1 & A2 & A3 & A4 & A5 & A6 & A7 & A8 & AIP \\
\hline Other product & $65 \%$ & $37 \%$ & $60 \%$ & $27 \%$ & $39 \%$ & $39 \%$ & $39 \%$ & $37 \%$ & $43 \%$ \\
New clothing & $18 \%$ & $49 \%$ & $12 \%$ & $61 \%$ & $51 \%$ & $29 \%$ & $39 \%$ & $46 \%$ & $38 \%$ \\
Energy recovery & $17 \%$ & $14 \%$ & $28 \%$ & $12 \%$ & $10 \%$ & $32 \%$ & $22 \%$ & $17 \%$ & $19 \%$ \\
\hline
\end{tabular}

From the preference analysis of the internal actors, three clusters corresponding to three sustainability profiles were identified. These profiles are based on existing literature on sustainability [32-34]: eco-efficiency, societal, and triple bottom line (TBL). Regarding the results of the AHP, and crossing them with the finding during the workshops and interviews, the resulting decision profiles can be explained as follows: 
Eco-efficiency: when adopting this profile, EDF is willing to reduce environmental impacts only if the economic expenses are kept at least stable with respect to the current model. Concerning the relationship with the suppliers, EDF adopts a prescriptive positioning rather than collaborative, e.g., the purchasing function asks for eco-innovative products to the providers.

Societal: this profile supposes a strong internal transformation of EDF's purchasing practices. For instance, the roles of sustainable development and human resources departments gain in importance in the definition of the purchasing strategy. Moreover, the purchasing department should be able to cooperate with the providers of the entire supply chain in order to accomplish sustainability goals from a normative perspective. Such a collaboration should be a common effort to transform the supply chain practices.

Triple bottom line (TBL): in this case, EDF is willing to pay a higher price for the safety clothing (i.e., degradation of economic dimension) if this reduces the environmental and social impacts, and guarantees the tracking and the quality of the product (i.e., improvement of environmental, social, and functional dimensions).

\section{Conclusions and Implications}

This paper contributes to the research in sustainable innovation, providing a framework that couples qualitative and quantitative research to support the collaborative process of sustainable innovation development at the early phases. Throughout an in-depth case study in EDF group, we found insights about the characteristics of sustainable innovations from the customer and the provider perspectives, determined by some dimensions and criteria. We also provide a guidance process based on a decision-aid method (AHP) to support the collaborative decision making process carried out with the key actors of the project. To validate the proposed framework, a first workshop involving the strategic internal actors (decision-makers from EDF) was carried out, who validated the results obtained. Then, we performed a second workshop facilitated by the PEAK cluster by Thésame (http:/ / www.peak-purchasing.com/, accessed on 1 July 2021) with the participation of several purchasing actors from public and private sectors, among which the Innovative Procurement function of the European Commission. This workshop allowed us to discuss the applicability of our framework to other contexts, providing us with some insights for future applications. Specifically, our work has some theoretical and managerial implications, explained in the following.

\subsection{Theoretical Implications}

Theoretically, we contributed to two main aspects: (i) the conceptualization of sustainable innovation (SI), (ii) the collaborative process between internal and external actors to develop SI.

Firstly, concerning the concept of sustainable innovation, our main contribution consists of proposing two additional dimensions to complete the concept of sustainable innovation, based on the three pillars of sustainability (economic, environmental, and social) $[2-4,30,58,65]$. Our study leads to two additional dimensions characterizing sustainable innovations, functional and relational. These two dimensions were added based on the EDF's needs, which considers that sustainable innovations should guarantee a good quality of products and services, and require trusty relationships with the providers. Regarding previous literature, the functional dimension was highlighted in the systematic review performed in [5] (referred to as the technical dimension in their study), and is considered as a main element from the innovation perspective. Nevertheless, in recent studies, the concept of SI is still defined by the three elements of sustainability $[4,30,58]$. Our study revealed that the functional dimension of SI is fundamental, namely, innovative products and services should primarily ensure that the satisfaction of the functional requirements of the customer is viable and then consider the other dimensions. Moreover, the relational dimension has been largely discussed in the literature and is recognised as a determinant of success for SI development $[4,15,47,51,52,57]$. In addition, throughout our study we found out that it 
also characterises the concept of SI. In line with [5], the relational dimension is inherent to the concept of SI, since engaged companies look beyond their boundaries, collaborating with external actors in their business environment to share resources and knowledge and facilitate transformations of a wider system. From our results, and considering EDF's appreciations, the relational dimension also consists of creating new and unique knowledge in collaboration with the involved actors.

Secondly, we also contribute to the literature about the Sustainable Innovation (SI) development process. Regarding previous literature, most of the authors develop a conceptual contribution to the SI development process [13-16,49], and ratify the necessity for collaborative methodologies or methods to guide the process. Little work has addressed this gap [17,54]. Based on an in-depth case study, our framework allows to analyse the customer needs and the provider abilities to match them into a collaborative logic. Our results are supported by the qualitative research insights based on interviews and longitudinal observation, and the deployment of a decision-aiding method (AHP). To position our contribution in this topic, with regards to the work in [54], the authors propose a method for supplier selection based on sustainability criteria, whereas the collaborative dimension of sustainable innovation is not addressed. Considering the work of [17], the author structures the SI development process into four moments, called "problematization", "intereressement", "enrolment", and "mobilization". These moments are comparable to the steps followed in the qualitative phase of our framework: definition of the project scope, setting actors' motivations, defining satisfaction criteria, and proposing SI solutions, which allows structuring the problem. In addition, the last phase of our framework performs a decision-aiding process based on AHP, resulting in the actors' preferred solutions and the identification of three sustainability-oriented profiles within the key internal actors.

The three profiles were identified regarding previous literature in sustainability $[32,33]$ : eco-efficiency, societal, and tripple bottom line (TBL). We analysed these profiles according to the ICOVET project results, adopting a collaborative perspective. For the eco-efficiency profile, there is a predominance of the collaboration between the purchasing and the prescription functions, with the support of the sustainable development function. As we observed, some actors provide a major importance to the product, as a means of reducing the environmental impacts (e.g., using recycling materials, reducing the quantity of raw material, etc.) Concerning the societal profile, the collaboration takes place between the sustainable development function and human resources, with the interfacing role of the purchasing function with the suppliers. Here, the efforts to achieve sustainable innovation are concentrated on the supplier management, according to the international standards $[35,36]$. Finally, in the TBL profile, in which and equal importance is accorded to each dimension of SI, there is a compensation effect between them and the purchasing decisions depend on punctual interests and needs at a given moment. Our findings further provide some managerial implications.

\subsection{Managerial Implications}

Firstly, the results of the project provided guiding elements for the company to design the future strategy of purchasing considering the sustainability criteria, for now applied to the safety clothing purchasing. Secondly, the results of the project provided the company with a methodological framework to carry out internal and external collaboration for the development of sustainability-oriented innovations.

From the internal perspective, the collective effort carried out along the ICOVET project resulted in a first step towards the transformation of EDF's purchasing strategy. The results obtained after the two years of the project revealed an improvement of the maturity on the purchasing function and the internal actors about the integration of sustainability-oriented criteria in the internal purchasing process. Although EDF is still constrained by the public procurement policies in France (i.e., any provider cannot be privileged by arbitrary selection criteria), the results of the project provide a base for discussion and co-creation with the provider panel, encouraging the development of sustainable and innovative solutions. Moreover, the results represent a first step towards the consolidation of new customer criteria 
regarding the safety clothing and sustainability goals, which can be reproduced within other buying companies and other purchasing sectors.

Concerning the collaborative dimension of sustainable innovation, the ICOVET project development and results provide some guidance for EDF to establish long-term relationships with the providers along the offer life cycle. One of the identified conditions stated by the providers to develop SI is the guarantee of long-term relationships and risk sharing agreements with the buyer company. In this line, EDF reinforced the relationships with its historical providers, and create new links with new ones able to engage into SI. The conditions to establish collaborative partnerships concern the contract duration, investments conditions, and knowledge sharing opportunities. The providers considered this panorama as an opportunity to progress rather than a constraint.

\subsection{Limits and Future Research}

This study has been deployed based on a single case study, which makes it difficult to generalize the results despite of the rigour and the deepness of the study. As a perspective, the proposed framework should be implemented in different industrial sectors for further validation. Secondly, although many actors in the textile supply chain were included in the problem delimitation phase, the framework should consider a more profound involvement of the suppliers, and eventually other purchasing organisations (horizontal collaboration) and non-economic actors (e.g., research centers, collaboration with public entities).

Author Contributions: Conceptualization, M.O. and C.L.-C.; methodology, M.O., C.L.-C., and K.M.; validation, M.O, C.L.-C., K.M., and G.N.; formal analysis, M.O., C.L.-C., and G.N.; investigation, M.O., C.L.-C., and G.N.; writing—original draft preparation, M.O.; writing-review and editing, C.L.-C. and K.M.; supervision, G.N.; funding acquisition, K.M. and G.N. All authors have read and agreed to the published version of the manuscript.

Funding: This work is partly supported by the Thomas Jefferson Fund through SUSTAIN project (https://perma.cc/596H-EVYN, accessed on 1 July 2021); and the PEAK Cluster by Thésame (http:/ / www.peak-purchasing.com/, accessed on 1 July 2021).

Institutional Review Board Statement: Not applicable.

Informed Consent Statement: Not applicable.

Conflicts of Interest: The authors declare no conflict of interest.

\section{References}

1. Nielsen, K.R. Policymakers' views on sustainable end-user innovation: Implications for sustainable innovation. J. Clean. Prod. 2020, 254, 120030. [CrossRef]

2. Klewitz, J.; Hansen, E.G. Sustainability-oriented innovation of SMEs: A systematic review. J. Clean. Prod. 2014, 65, 57-75. [CrossRef]

3. Rohrbeck, R.; Konnertz, L.; Knab, S. Collaborative business modelling for systemic and sustainability innovations. Int. J. Technol. Manag. 2013, 63, 4-23. [CrossRef]

4. Berkowitz, H. Meta-organizing firms' capabilities for sustainable innovation: A conceptual framework. J. Clean. Prod. 2018, 175, 420-430. [CrossRef]

5. Adams, R.; Jeanrenaud, S.; Bessant, J.; Denyer, D.; Overy, P. Sustainability-oriented innovation: A systematic review. Int. J. Manag. Rev. 2016, 18, 180-205. [CrossRef]

6. Aboelmaged, M.; Hashem, G. Absorptive capacity and green innovation adoption in SMEs: The mediating effects of sustainable organisational capabilities. J. Clean. Prod. 2019, 220, 853-863. [CrossRef]

7. Anttonen, M.; Halme, M.; Houtbeckers, E.; Nurkka, J. The other side of sustainable innovation: Is there a demand for innovative services? J. Clean. Prod. 2013, 45, 89-103. [CrossRef]

8. Foxon, T.; Pearson, P. Overcoming barriers to innovation and diffusion of cleaner technologies: Some features of a sustainable innovation policy regime. J. Clean. Prod. 2008, 16, 148-161. [CrossRef]

9. Pinto, M.M.A.; Kovaleski, J.L.; Yoshino, R.T.; Pagani, R.N. Knowledge and Technology Transfer Influencing the Process of Innovation in Green Supply Chain Management: A Multicriteria Model Based on the DEMATEL Method. Sustainability 2019, 11, 3485. [CrossRef]

10. Huang, J.W.; Li, Y.H. Green innovation and performance: The view of organizational capability and social reciprocity. J. Bus. Ethics 2017, 145, 309-324. [CrossRef] 
11. Mousavi, S.; Bossink, B.A. Firms' capabilities for sustainable innovation: The case of biofuel for aviation. J. Clean. Prod. 2017, 167, 1263-1275. [CrossRef]

12. Ferigotti, C.M.; Cunha, S.K.; Fernandes, B.H.R. Managerial competencies for requirements of sustainable innovation: The case of Electrolux of Brazil S/A. Int. J. Innov. Sustain. Dev. 2016, 10, 160-176. [CrossRef]

13. Brix, J. Building capacity for sustainable innovation: A field study of the transition from exploitation to exploration and back again. J. Clean. Prod. 2020, 268, 122381. [CrossRef]

14. Kuokkanen, A.; Uusitalo, V.; Koistinen, K. A framework of disruptive sustainable innovation: An example of the Finnish food system. Technol. Anal. Strateg. Manag. 2019, 31,749-764. [CrossRef]

15. Neutzling, D.M.; Land, A.; Seuring, S.; do Nascimento, L.F.M. Linking sustainability-oriented innovation to supply chain relationship integration. J. Clean. Prod. 2018, 172, 3448-3458. [CrossRef]

16. Reficco, E.; Gutiérrez, R.; Jaén, M.H.; Auletta, N. Collaboration mechanisms for sustainable innovation. J. Clean. Prod. 2018, 203, 1170-1186. [CrossRef]

17. Aka, K.G. Actor-network theory to understand, track and succeed in a sustainable innovation development process. J. Clean. Prod. 2019, 225, 524-540. [CrossRef]

18. Mercado-Caruso, N.; Segarra-Oña, M.; Ovallos-Gazabon, D.; Peiró-Signes, A. Identifying endogenous and exogenous indicators to measure eco-innovation within clusters. Sustainability 2020, 12, 6088. [CrossRef]

19. Cheng, C.C. Sustainability orientation, green supplier involvement, and green innovation performance: Evidence from diversifying green entrants. J. Bus. Ethics 2020, 161, 393-414. [CrossRef]

20. Wang, J.; Xue, Y.; Sun, X.; Yang, J. Green learning orientation, green knowledge acquisition and ambidextrous green innovation. J. Clean. Prod. 2020, 250, 119475. [CrossRef]

21. Abbas, J.; Sağsan, M. Impact of knowledge management practices on green innovation and corporate sustainable development: A structural analysis. J. Clean. Prod. 2019, 229, 611-620. [CrossRef]

22. Seman, N.A.A.; Govindan, K.; Mardani, A.; Zakuan, N.; Saman, M.Z.M.; Hooker, R.E.; Ozkul, S. The mediating effect of green innovation on the relationship between green supply chain management and environmental performance. J. Clean. Prod. 2019, 229, 115-127. [CrossRef]

23. Soewarno, N.; Tjahjadi, B.; Fithrianti, F. Green innovation strategy and green innovation. Manag. Decis. 2019, 57, 3061-3078. [CrossRef]

24. Tariq, A.; Badir, Y.F.; Safdar, U.; Tariq, W.; Badar, K. Linking firms' life cycle, capabilities, and green innovation. J. Manuf. Technol. Manag. 2019, 31, 284-305. [CrossRef]

25. Wang, C.H. How organizational green culture influences green performance and competitive advantage. J. Manuf. Technol. Manag. 2019, 30, 666-683. [CrossRef]

26. de Medeiros, J.F.; Vidor, G.; Ribeiro, J.L.D. Driving factors for the success of the green innovation market: A relationship system proposal. J. Bus. Ethics 2018, 147, 327-341. [CrossRef]

27. Saunila, M.; Ukko, J.; Rantala, T. Sustainability as a driver of green innovation investment and exploitation. J. Clean. Prod. 2018, 179, 631-641. [CrossRef]

28. Cuerva, M.C.; Triguero-Cano, Á.; Córcoles, D. Drivers of green and non-green innovation: Empirical evidence in Low-Tech SMEs. J. Clean. Prod. 2014, 68, 104-113. [CrossRef]

29. Weidner, K.; Nakata, C.; Zhu, Z. Sustainable innovation and the triple bottom-line: A market-based capabilities and stakeholder perspective. J. Mark. Theory Pract. 2021, 29, 141-161. [CrossRef]

30. Dyck, B.; Silvestre, B.S. Enhancing socio-ecological value creation through sustainable innovation 2.0: Moving away from maximizing financial value capture. J. Clean. Prod. 2018, 171, 1593-1604. [CrossRef]

31. WCED, S.W.S. World commission on environment and development. Our Common Future 1987, $17,1-91$.

32. Pope, J.; Morrison-Saunders, A.; Annandale, D. Applying sustainability assessment models. Impact Assess. Proj. Apprais. 2005, 23, 293-302. [CrossRef]

33. Vezzoli, C.; Manzini, E. Design for Environmental Sustainability; Springer: London, UK, 2008.

34. Bond, A.; Morrison-Saunders, A.; Pope, J. Sustainability assessment: The state of the art. Impact Assess. Proj. Apprais. 2012, 30, 53-62. [CrossRef]

35. ISO 14001. Environmental Management System: Requirements with Guidance for Use; International Organization for Standardization: Geneva, Switzerland, 2015.

36. ISO 26000. Guidance on Social Responsibility; International Organization for Standardization: Geneva, Switzerland, 2010.

37. Carrillo-Hermosilla, J.; del Río, P.; Könnölä, T. Diversity of eco-innovations: Reflections from selected case studies. J. Clean. Prod. 2010, 18, 1073-1083. [CrossRef]

38. Barile, S.; Grimaldi, M.; Loia, F.; Sirianni, C.A. Technology, value Co-Creation and innovation in service ecosystems: Toward sustainable Co-Innovation. Sustainability 2020, 12, 2759. [CrossRef]

39. Brown, P.; Bocken, N.; Balkenende, R. Why do companies pursue collaborative circular oriented innovation? Sustainability 2019, 11, 635. [CrossRef]

40. Delmas, M.A.; Pekovic, S. Corporate sustainable innovation and employee behavior. J. Bus. Ethics 2018, 150, 1071-1088. [CrossRef]

41. Van de Wetering, R.; Mikalef, P.; Helms, R. Driving organizational sustainability-oriented innovation capabilities: A complex adaptive systems perspective. Curr. Opin. Environ. Sustain. 2017, 28, 71-79. [CrossRef] 
42. Abdullah, M.; Zailani, S.; Iranmanesh, M.; Jayaraman, K. Barriers to green innovation initiatives among manufacturers: The Malaysian case. Rev. Manag. Sci. 2016, 10, 683-709. [CrossRef]

43. Huang, X.x.; Hu, Z.p.; Liu, C.s.; Yu, D.j;; Yu, L.f. The relationships between regulatory and customer pressure, green organizational responses, and green innovation performance. J. Clean. Prod. 2016, 112, 3423-3433. [CrossRef]

44. Zailani, S.; Govindan, K.; Iranmanesh, M.; Shaharudin, M.R.; Chong, Y.S. Green innovation adoption in automotive supply chain: The Malaysian case. J. Clean. Prod. 2015, 108, 1115-1122. [CrossRef]

45. Costa, J.; Matias, J.C. Open innovation 4.0 as an enhancer of sustainable innovation ecosystems. Sustainability $2020,12,8112$. [CrossRef]

46. Zhou, M.; Govindan, K.; Xie, X. How fairness perceptions, embeddedness, and knowledge sharing drive green innovation in sustainable supply chains: An equity theory and network perspective to achieve sustainable development goals. J. Clean. Prod. 2020, 260, 120950. [CrossRef]

47. Awan, U.; Sroufe, R.; Kraslawski, A. Creativity enables sustainable development: Supplier engagement as a boundary condition for the positive effect on green innovation. J. Clean. Prod. 2019, 226, 172-185. [CrossRef]

48. Maletič, M.; Maletič, D.; Dahlgaard, J.J.; Dahlgaard-Park, S.M.; Gomišček, B. Effect of sustainability-oriented innovation practices on the overall organisational performance: An empirical examination. Total Qual. Manag. Bus. Excell. 2016, 27, 1171-1190. [CrossRef]

49. Cantele, S.; Moggi, S.; Campedelli, B. Spreading sustainability innovation through the co-evolution of sustainable business models and partnerships. Sustainability 2020, 12, 1190. [CrossRef]

50. Goodman, J.; Korsunova, A.; Halme, M. Our collaborative future: Activities and roles of stakeholders in sustainability-oriented innovation. Bus. Strategy Environ. 2017, 26, 731-753. [CrossRef]

51. Melane-Lavado, A.; Álvarez-Herranz, A. Cooperation Networks as a Driver of Sustainability-Oriented Innovation. Sustainability 2020, 12, 2820. [CrossRef]

52. Inigo, E.A.; Ritala, P.; Albareda, L. Networking for sustainability: Alliance capabilities and sustainability-oriented innovation. Ind. Mark. Manag. 2020, 89, 550-565. [CrossRef]

53. Chen, X.; Yi, N.; Zhang, L.; Li, D. Does institutional pressure foster corporate green innovation? Evidence from China's top 100 companies. J. Clean. Prod. 2018, 188, 304-311. [CrossRef]

54. Gupta, H.; Barua, M.K. Supplier selection among SMEs on the basis of their green innovation ability using BWM and fuzzy TOPSIS. J. Clean. Prod. 2017, 152, 242-258. [CrossRef]

55. Hernandez-Vivanco, A.; Bernardo, M.; Cruz-Cázares, C. Sustainable innovation through management systems integration. J. Clean. Prod. 2018, 196, 1176-1187. [CrossRef]

56. Lee, D. Implementation of collaborative activities for sustainable supply chain innovation: An analysis of the firm size effect. Sustainability 2019, 11, 3026. [CrossRef]

57. Ghassim, B.; Bogers, M. Linking stakeholder engagement to profitability through sustainability-oriented innovation: A quantitative study of the minerals industry. J. Clean. Prod. 2019, 224, 905-919. [CrossRef]

58. Rauter, R.; Perl-Vorbach, E.; Baumgartner, R.J. Is open innovation supporting sustainable innovation? Findings based on a systematic, explorative analysis of existing literature. Int. J. Innov. Sustain. Dev. 2017, 11, 249-270. [CrossRef]

59. Eisenhardt, K.M. Building Theories from Case Study Research. Acad. Manag. Rev. 1989, 14, 532-550. [CrossRef]

60. Yin, R.K. Case Study Research and Applications: Design and Methods; Sage Publications: Los Angeles, CA, USA, 2017.

61. Miles, M.B.; Huberman, A.M.; Saldaña, J. Qualitative Data Analysis: A Methods Sourcebook, 3rd ed.; SAGE Publications: Thousand Oaks, CA, USA, 2014.

62. Saaty, T.L. Decision making-The analytic hierarchy and network processes (AHP/ANP). J. Syst. Sci. Syst. Eng. 2004, 13, 1-35. [CrossRef]

63. Dos Santos, P.H.; Neves, S.M.; Sant'Anna, D.O.; de Oliveira, C.H.; Carvalho, H.D. The analytic hierarchy process supporting decision making for sustainable development: An overview of applications. J. Clean. Prod. 2019, 212, 119-138. [CrossRef]

64. Karthik, T.; Rathinamoorthy, R. Sustainable synthetic fibre production. In Sustainable Fibres and Textiles; Elsevier: Amsterdam, The Netherlands, 2017; pp. 191-240.

65. Boons, F.; Lüdeke-Freund, F. Business models for sustainable innovation: State-of-the-art and steps towards a research agenda. J. Clean. Prod. 2013, 45, 9-19. [CrossRef] 